\title{
EFFECT OF AEROBIC AND LOAD EXERCISES ON BODY FAT AND LUNG VITAL CAPACITY
}

\author{
Rina Yuniana ${ }^{1}$ \\ ${ }^{1}$ Ilmu Keolahragaan, Fakultas Ilmu Keolahragaan Universitas Negeri Yogyakarta Jl. Colombo No. 1, \\ Karangmalang Depok, Sleman, Yogyakarta, Indonesia \\ rinayuniana@uny.ac.id
}

\begin{abstract}
This study aims to determine how much influence aerobic exercise and weight training have on body fat and vital capacity. This study used an experimental method with a randomized control group pretest-posttest design. The population in this study were 68 female members at the Fitness Center, Faculty of Sport Science, Yogyakarta State University who participated in the weight loss program. The sample in this study was taken purposively by determining the number of members who participated in the training program with the criteria that active members were at least 2 months practicing before the treatment was carried out and women aged 18-25 years. Through these criteria, the sample obtained is as many as 54 people. Of the 54 people, they were divided randomly into three groups, namely the aerobic exercise group of 18 people, the weight training group of 18 people, and the control group of 18 people. The instrument used to measure and collect body fat data used a skinfold caliper, while the vital lung capacity was measured using a spirometer with a Vitalograph brand. The data analysis technique used the normality test, namely the KolmogorovSmirnov Test. This test is carried out to determine whether the data has a normal distribution. The homogeneity test used the Levene's Test with the F test. To test the research hypothesis, it was done using Analysis of Variance (ANOVA). This test was conducted to determine the difference in the mean value of the variables between the pretest and posttest in the experimental group. The results of the research analysis showed that aerobic exercise can reduce body fat by $4.651 \%$ and increase the vital lung capacity of members at the Fitness Center by 0.2167 liters / BTPS. Weight training can reduce body fat by $2.969 \%$. Weight training can increase the vital capacity of the lungs by 0.1583 liters / BTPS. Aerobic exercise can reduce body fat by $1.68617 \%$ higher than weight training. Aerobic exercise can increase the ability of vital lung capacity 0.05833 liters / BTPS higher than weight training.
\end{abstract}

Keywords: aerobic exercise, weight training, circuits, body fat, vital lung capacity

\section{PENGARUH LATIHAN AEROBIK DAN LATIHAN BEBAN TERHADAP LEMAK TUBUH DAN KAPASITAS VITAL PARU}

\begin{abstract}
Abstrak
Penelitian ini bertujuan untuk mengetahui seberapa besar pengaruh latihan aerobik dan latihan beban terhadap lemak tubuh dan kapasitas vital. Penelitian ini menggunakan metode eksperimen dengan Randomized Control Group Pretest-Posttest Desain. Populasi pada penelitian ini adalah member perempuan di Fitness Center Fakultas Ilmu Keolahragaan Universitas Negeri Yogyakarta yang mengikuti program penurunan berat badan yaitu sebanyak 68 orang. Sampel pada penelitian diambil secara purposive dengan menentukan jumlah member yang mengikuti program latihan dengan kriteria yaitu member aktif minimal 2 bulan berlatih sebelum perlakuan dilaksanakan dan wanita usia 18-25 tahun. Melalui kriteria tersebut maka sampel yang diperoleh yaitu sebanyak 54 orang. Dari 54 orang tersebut dibagi menjadi tiga kelompok secara random, yaitu kelompok latihan aerobik sebanyak 18 orang, kelompok latihan beban sebanyak 18 orang, dan kelompok kontrol sebanyak 18 orang. Instrumen yang digunakan untuk mengukur dan mengumpulkan data lemak tubuh dengan
\end{abstract}


menggunakan skinfold caliper, sedangkan untuk mengukur kemampuan kapasitas vital paru menggunakan spirometer Merk Vitalograph. Teknik analisis data menggunakan uji normalitas yaitu Kolmogorov-Smirnov Test. Uji ini dilakukan untuk mengetahui apakah data mempunyai sebaran yang berdistribusi normal. Uji homogenitas menggunakan uji Levene's Test dengan uji F. Untuk menguji hipotesis penelitian dilakukan dengan menggunakan Analisis Variansi (ANAVA). Uji ini dilakukan untuk mengetahui perbedaan rerata nilai dari variabel antara pretest dan posttest pada kelompok eksperimen. Hasil analisis penelitian menunjukkan bahwa latihan aerobik dapat menurunkan lemak tubuh sebesar 4,651 \% dan meningkatkan kapasitas vital paru pada member di Fitness Center sebesar 0,2167 liter/BTPS. Latihan beban dapat menurunkan lemak tubuh sebesar $2,969 \%$. Latihan beban dapat meningkatkan kapasitas vital paru sebesar 0,1583 liter/BTPS. Latihan aerobik dapat menurunkan lemak tubuh lebih tinggi 1,68617\% dibanding latihan beban. Latihan aerobik dapat meningkatkan kemampuan kapasitas vital paru lebih tinggi 0,05833 liter/BTPS dibanding latihan beban.

Kata Kunci : latihan aerobik, latihan beban, sirkuit, lemak tubuh, kapasitas vital paru

\section{PENDAHULUAN}

Di era globalisasi ini, berbagai macam aktivitas yang dilakukan manusia sangat padat dan beraneka ragam. Pola hidup setiap orang pun sangat berbeda-beda. Kebanyakan orang menginginkan hidup serba praktis, serta semua kebutuhan dapat terpenuhi tanpa timbul rasa capek ataupun kelelahan yang berkepanjangan. Pergeseran pola hidup dari bekerja aktif secara dinamis menjadi jarang bekerja atau pasif merupakan suatu penyebab menurunnya tingkat kebugaran seseorang. Hal tersebut merupakan dampak negatif atau akibat dari kemajuan teknologi. Banyak orang atau perusahaan yang menciptakan peralatan serba otomatis dan praktis, yang digunakan sebagai pengganti kerja manusia. Alat tersebut digunakan untuk mengganti dan meringankan kerja setiap orang, dimana orang yang seharusnya bekerja atau beraktivitas secara fisik misalnya jalan untuk menuju suatu tempat kerja, diganti dengan menggunakan sepeda motor atau kendaraan lainnya, sehingga orang akan pasif dan bermalas-malasan.

Keadaan kurangnya gerak (hypokinetic) seperti itu dapat menyebabkan berbagai problema kesehatan, di mana problema tersebut sangat berbahaya bagi kehidupan manusia. Munculnya berbagai macam penyakit merupakan dampak yang paling nyata dari pola hidup yang kurang sehat. Adapun penyakit yang sering muncul di antaranya jantung koroner, diabetes millitus, hipertensi, penyakit sendi, kelebihan berat badan (overweight) bahkan sampai kegemukan (obesitas) dan lain sebagainya.

Kelebihan berat badan merupakan keadaan ketidakseimbangan antara masa tubuh dengan keadaan lemak tubuh, di mana terjadi penumpukan lemak yang berlebihan di jaringan adifosa. Keadaan ini timbul akibat dari pengaturan makan yang tidak baik serta gaya hidup yang kurang gerak (hypokinetic). Kelebihan asupan makanan yang dikonsumsi secara akumulatif akan ditimbun atau disimpan sebagai cadangan energi berupa lemak tubuh. Ketidakseimbangan antara energi yang masuk dengan energi yang dikeluarkan atau digunakan oleh tubuh inilah yang mengakibatkan berat badan semakin bertambah, sehingga terjadi kelebihan pada berat badan.

Orang yang sadar akan hidupnya, pasti ingin memiliki tubuh yang sehat dan bugar, ingin terhindar dari berbagai penyakit, serta ingin memiliki tubuh yang ideal dan proporsional, karena tubuh ideal dapat menunjang penampilan seseorang sehingga dapat menimbulkan rasa percaya diri. Lain halnya dengan orang-orang yang memiliki kelebihan berat badan. Orang tersebut akan merasa malu bahkan minder dengan tubuh yang dimilikinya, sehingga hal ini dapat menurunkan rasa percaya diri pada seseorang. Selain itu, orang-orang yang memiliki kelebihan berat badan akan rentan terhadap penyakit yang berbahaya bagi hidupnya. Agar hal tersebut tidak terjadi, maka setiap orang harus 
melakukan pola hidup yang sehat dengan berolahraga/ melakukan latihan, makan yang seimbang serta istirahat yang cukup.

Bentuk latihan untuk menurunkan berat badan sangat bermacam-macam. Adapun bentuk latihan yang dapat digunakan yaitu menggunakan latihan aerobik seperti lari, jongging, berenang, bersepeda, senam aerobik dan lain sebagainya. Secara fisiologis, latihan aerobik dapat meningkatkan kerja paru jantung, dimana sistem tersebut dapat memperlancar sirkulasi peredaran darah dari dan ke jantung untuk dialirkan ke otak dan seluruh tubuh sehingga disaat melakukan olahraga atau latihan, sistem metabolisme di dalam tubuh akan menjadi lancar. Selain itu, latihan aerobik juga dapat membakar lemak dalam tubuh sebagai akibat dari latihan aerobik yang dilakukan dalam waktu yang relatif lama. Sistem inilah yang dapat menghasilkan energi yang diperoleh dari makanan yang digunakan untuk proses gerak ataupun latihan. Gerak atau latihan juga dapat meningkatkan daya tahan otot pada manusia.

Selain itu, latihan juga dapat dilakukan dengan latihan beban. Latihan beban adalah latihan menggunakan beban untuk meningkatkan kemampuan seseorang dalam mengerahkan kekuatan dengan tujuan meningkatkan kekuatan, daya tahan otot, hipertrofi, kinerja atlet atau kombinasi dari tujuan tersebut (Baechle, 2012). Sedangkan Baechle (2014) mengatakan bahwa latihan beban banyak digunakan oleh para penggemar kebugaran, karena latihan beban merupakan aktivitas yang dapat dicapai dalam waktu singkat, namun dapat secara dramatis mengubah bentuk tubuh. Werner (2011) berpendapat bahwa latihan beban merupakan sebuah program yang dirancang untuk meningkatkan kekuatan otot dan daya tahan tubuh melalui serangkaian latihan beban secara progresif yang membebani sistem otot dan menyebabkan perkembangan fisiologis.

Latihan beban merupakan latihan yang dilakukan secara sistematis dengan menggunakan beban sebagai alat untuk menambah kekuatan fungsi otot guna memperbaiki kondisi fisik, mencegah terjadinya cedera atau untuk tujuan kesehatan. Latihan beban dapat dilakukan dengan menggunakan beban dari berat badan sendiri (beban dalam) atau menggunakan beban luar yaitu beban bebas (free weight) seperti dumbell, barbell, atau mesin beban (gym machine). Senada dengan pendapat Baechle, (2012) bahwa latihan beban dapat menggunakan beban bebas, berat badan pengangkat sendiri, mesin, atau perangkat lain untuk mencapai tujuan latihan. Bentuk latihan yang menggunakan beban dalam yang paling banyak digunakan seperti chin-up, push-up, sit-up, ataupun back-up, sedangkan menggunakan beban luar sangatlah banyak dan bervariasi sesuai dengan tujuan latihan.

Latihan beban juga dapat dijadikan sarana seseorang untuk menurunkan berat badan (fatloss), menaikkan berat badan, hipertrofi, pengencangan, kebugaran dan juga rehabilitasi pasca cedera (Nasrulloh, 2018). Latihan beban dapat dilakukan dengan berbagai metode untuk mencapai tujuan latihan. Salah satu metode latihan beban yang sering dilakukan dengan tujuan untuk menurunkan berat badan yaitu metode sirkuit. Latihan selanjutnya yaitu latihan beban secara sirkuit. Latihan ini pada dasarnya adalah memadukan latihan beban dengan prinsip latihan sirkuit, pada awalnya latihan ini dirancang untuk meningkatkan daya tahan dan kekuatan otot sambil melatih sistem aerobik, selanjutnya berkembang untuk memperbaiki komposisi tubuh. Latihan beban ini terdiri atas beberapa macam latihan beban yang disusun menjadi beberapa station atau pos, dengan pembebanan ringan ulangan banyak, dilakukan beberapa sirkuit, di antara pos diberikan istirahat pendek atau tanpa istirahat, sedangkan di antara sirkuit diberikan istirahat yang lebih lama (Djoko, 2009).

Turunnya berat badan dapat dilihat dari turunnya persentase lemak dalam tubuh. Menurut Djoko (2004), kualitas komposisi badan manusia dinyatakan dengan persentase lemak tubuh. Seorang pria dikategorikan berbadan normal jika memiliki lemak badan $15 \%$ $20 \%$, sedangkan putri $20 \%-25 \%$. Selain itu, ukuran badan manusia dapat pula diprediksi 
dengan formula berat badan ideal (BBI) dari Broucha. Kelebihan 10\% di atas BBI termasuk kategori berat badan normal (BBN), sedangkan kelebihan di atas $10 \%-25 \%$ untuk pria dan di atas 10\% - 30\% untuk wanita termasuk kategori berat badan berlebih (overweight), selebihnya dikategorikan kegemukan (obesytas). Lemak adalah garam yang terjadi dari penyatuan asam lemak dengan alkohol organik yang disebut gliserol atau gliserin. Lemak yang dapat mencair dalam temperatur biasa disebut minyak, sedangkan dalam bentuk padat disebut lemak. Seperti halnya karbohidrat, lemak tersusun atas molekul C, H, dan O dengan jumlah atom lebih banyak, misalnya: stearin C57 H110O6 (Djoko, 2007). Oleh karena itu sangat dianjurkan untuk melakukan latihan atau olahraga untuk dapat mengontrol lemak tubuh supaya selalu dalam keadaan normal.

Pada saat latihan, mengatur nafas merupakan aspek yang penting, tetapi kadangkadang malah terabaikan oleh para olahragawan. Kecenderungan yang terjadi adalah menahan nafas selama fase pengeluaran tenaga. Cara ini tidak benar, karena jika pengeluaran nafas (ekspirasi) maupun inspirasi tidak teratur maka akan berakibat pada berkurangnya jumlah oksigen, sehingga pada gilirannya oksigen yang menuju ke otak akan berkurang. Selain itu, disaat menahan nafas atau tidak mengeluarkan nafas saat kontraksi maka hal tersebut dapat mengurangi kembalinya darah ke jantung dan otak, sehingga otak tidak akan menerima darah yang kaya akan oksigen. Apabila hal ini terjadi maka akan berakibat pada orang yang latihan tersebut. Orang tersebut akan merasa pusing dan lama kelamaan bisa mengakibatkan orang itu tidak sadarkan diri atau pingsan (Thomas.R, 1996). Cara yang benar adalah pada saat mengangkat beban maka keluarkan nafas dengan cara menghembuskan nafas melalui mulut. Nafas tersebut jangan sampai ditahan karena akan berakibat pada organ tubuh lainnya. Sistem pernafasan yang benar pada saat latihan beban yaitu mengeluarkan nafas saat melakukan konstraksi atau mengangkat beban dan menarik nafas pada saat mengendorkan otot (relaksasi).

Kapasitas vital paru adalah jumlah udara maksimal pada ekspirasi kuat, setelah inspirasi maksimal (Junusul, 1989). Menurut Sony (2005) kapasitas vital paru (Vital Capacity/VC) adalah volume udara yang dapat dicapai masuk dan keluar paru-paru pada penarikan napas paling kuat, diukur dengan alat spirometer. Sedangkan menurut Evelyn yang dikutip oleh Sugiarto dan Nanang (2007) kapasitas vital yaitu volume udara yang dapat dicapai masuk dan keluar paru pada penarikan nafas dan pengeluaran nafas paling kuat. Guyton (1997) mendefinisikan kapasitas vital adalah volume cadangan inspirasi ditambah volume tidal dan volume cadangan ekspirasi ini adalah jumlah udara maksimum yang dapat dikeluarkan dari paru seseorang setelah mengisi sampai batas maksimum dan kemudian mengeluarkan sebanyak-banyaknya.

Keadaan paru secara umum merupakan bawaan dari dalam kandungan yang pada perkembangannya akan mengalami latihan sesuai proses respirasi yang dilakukan. Paru dapat dikembangkempisan oleh: 1) gerakan naik turun diafragma untuk memperbesar atau memperkecil rongga dada, 2) elevasi dan depresi iga-iga untuk meningkatkan dan menurunkan diameter antero-posterior rongga dada (Guyton, 1997). Berbagai macam volume dan kapasitas paru tidak hanya dipengaruhi oleh ukuran dan pengembangan tubuh, tetapi juga oleh posisi tubuh. Apabila seseorang dalam keadaan berbaring, sebagian besar volume akan menurun. Hal ini disebabkan oleh dua faktor. Pertama, organ-organ yang ada di dalam rongga perut cenderung mendorong diafragma dan sebagai akibatnya akan mempengaruhi gravitasi pada posisi telentang, dan kedua, karena terjadi peningkatan volume darah pulmoner sebagai hasil dari perubahan tekanan tekanan hemodinamik (Junusul, 1989).

Kapasitas vital dipengaruhi oleh posisi tubuh, kekuatan otot-otot pernapasan, kemampuan paru dan rongga dada untuk berkembang. Bila dikaitkan dengan usia dan pertumbuhan, seseorang dengan usia semakin tua, kemampuan kontraksi ototnya menurun 
termasuk otot-otot pernapasannya. Hal ini berpengaruh pada kemampuan paru untuk menampung udara, tetapi apabila rongga dada terbenam dalam air, seperti penimbangan berat badan dalam air, maka kapasitas vital sedikit menurun. Kapasitas vital paru rata-rata pada pria dewasa muda kira-kira 4,6 liter dan pada wanita dewasa muda kira-kira 3,1 liter, meskipun nilai-nilai ini jauh lebih besar pada orang dengan berat badan yang sama dengan orang lain. Orang tinggi kurus biasanya mempunyai kapasitas vital yang lebih besar daripada orang gemuk, dan seorang atlet yang terlatih mempunyai kapasitas 30-40\% di atas normal, yaitu 6-7 liter (Guyton, 1997). Kapasitas vital pada pria normalnya 4-5 liter, sedangkan kapasitas vital pada wanita normalnya 3-4 liter (Sugiarto dan Nanang, 2007). Oleh karena itu, dalam penelitian ini akan dilakukan beberapa perlakukan tentang latihan aerobik dan latihan beban dengan metode sirkuit untuk mengetahui pengaruhnya terkadap persentase lemak tubuh dan kapasitas vital paru.

\section{METODE}

Penelitian ini merupakan penelitian eksperimen. Desain dalam penelitian ini menggunakan Randomized Control Group Pretest-Posttest Desain. Desain ini bentuknya sederhana, terdiri dari satu atau lebih kelompok perlakuan dan sebuah control (Nazir, 2003). Dengan model ini, peneliti ingin mengecek ada tidaknya carry-over effect dan atau practiceeffect dari adanya pretest. Desain penelitian tersebut dapat dijelaskan bahwa semua subjek penelitian diberikan tes awal dengan mengukur lemak tubuh dan mengukur kapasitas vital paru. Penelitian ini dilakukan pada dua kelompok eksperimen yang diberi perlakuan sesuai dengan latihannya yaitu dengan latihan aerobik dan latihan beban. Setelah subjek penelitian diberikan perlakuan, maka tahap terakhir yaitu dilakukan tes akhir (posttest). Apabila pada akhirnya terdapat perbedaan antara pretest dan posttest, maka hal itu disebabkan oleh pengaruh dari perlakuan yang diberikan dari masing-masing kelompok.

Metode latihan yang diberikan dalam perlakuan adalah dengan latihan aerobik dan latihan beban dengan metode sirkuit. Latihan aerobik adalah latihan dimana proses pemenuhan kebutuhan energi atau tenaga untuk bergerak di dalam tubuh memerlukan bantuan oksigen dari luar tubuh manusia. Latihan aerobik yang dilakukan yaitu lari atau jogging. Latihan ini dilakukan di dalam ruangan dengan menggunakan treadmill atau mesin lari. Sedangkan latihan beban dengan sirkuit adalah program latihan yang memadukan latihan beban dengan prinsip latihan sirkuit atau kontinyu yang terdiri atas beberapa macam latihan beban yang disusun menjadi beberapa station atau pos, dengan pembebanan ringan ulangan banyak, dilakukan beberapa seri atau sirkuit, di antara pos diberikan istirahat pendek atau tanpa istirahat, sedangkan di antara sirkuit diberikan istirahat yang lebih lama. Selain itu terdiri atas beberapa jenis latihan, istirahat antar latihan sedikit, repetisi atau ulangan banyak, menggunakan beban ringan, latihan dimulai dari otot kecil ke otot besar, dilakukan bergantian antara anggota gerak atas dan bawah.

\section{HASIL PENELITIAN}

Pengujian ini bertujuan untuk mengetahui perbedaan mean/rerata antara pretest dengan posttest pada variabel bebas yang meliputi: lemak tubuh dan kapasitas vital paru pada masing-masing kelompok perlakuan. Hasil analisis dinyatakan terdapat perbedaan jika nilai signifikansi kurang dari 0,05 $(\mathrm{P}<0,05)$.

\section{Hasil Uji beda Variabel Terikat Kelompok Latihan Aerobik}

Hasil analisis perbedaan antara pretest dengan posttets variabel lemak tubuh dan kemampuan kapasitas vital paru pada kelompok latihan aerobik dapat disajikan pada Tabel 1 berikut: 
Tabel 1. Hasil Analisis Uji Beda Variabel Terikat Pada Kelompok Latihan Aerobik

\begin{tabular}{lcccccl}
\hline \multirow{2}{*}{ Variabel } & \multicolumn{2}{c}{ Mean } & $\begin{array}{c}\text { Mean } \\
\text { Delta }\end{array}$ & T test & $\begin{array}{c}\text { P } \\
(\text { Sig. })\end{array}$ & \multicolumn{1}{c}{ Ket } \\
\cline { 2 - 6 } $\begin{array}{l}\text { Lemak } \\
\text { Tubuh }\end{array}$ & 30,5728 & 25,9217 & 4,65111 & 11,417 & 0,000 & $\begin{array}{l}\text { P<0,05 } \\
\text { (Beda Signifikan) }\end{array}$ \\
\hline $\begin{array}{l}\text { Kapasitas } \\
\text { Vital Paru }\end{array}$ & 2,8056 & 3,0222 & $-0,21667$ & $-6,807$ & 0,000 & $\begin{array}{l}\text { P<0,05 } \\
\text { (Beda Signifikan) }\end{array}$ \\
\hline
\end{tabular}

Hasil analisis sesuai pada tabel di atas menunjukkan bahwa pada kelompok latihan aerobik terdapat perbedaan antara pretest dengan posttest. Variabel lemak tubuh memiliki nilai $\mathrm{p}=0,000$, dimana $\mathrm{p}<0,05$ berarti ada perbedaan bermakna dan untuk variabel kapasitas vital paru memiliki nilai $\mathrm{p}=0,000$, dimana $\mathrm{p}<0,05$ berarti ada perbedaan bermakna. Berdasarkan analisis tersebut di atas dapat diartikan bahwa latihan aerobik dapat menurunkan lemak tubuh sebanyak 4,65111 \% dan dapat meningkatkan kemampuan kapasitas vital paru sebesar 0,21667 liter/BTPS.

\section{Hasil Uji beda Variabel Terikat Kelompok Latihan Beban}

Hasil analisis perbedaan antara pretest dengan posttets variabel lemak tubuh dan kemampuan kapasitas vital paru pada kelompok latihan beban dapat disajikan pada Tabel 2 berikut:

Tabel 2. Hasil Analisis Uji Beda Variabel Terikat Pada Kelompok Latihan Beban

\begin{tabular}{lcccccl}
\hline \multicolumn{1}{c}{ Variabel } & \multicolumn{2}{c}{ Mean } & $\begin{array}{c}\text { Mean } \\
\text { Delta }\end{array}$ & T test & $\begin{array}{c}\text { P } \\
\text { (Sig.) }\end{array}$ & \multicolumn{1}{c}{ Ket } \\
\cline { 2 - 3 } $\begin{array}{l}\text { Lemak } \\
\text { Tubuh }\end{array}$ & 28,5267 & 25,5572 & 2,9695 & 10,040 & 0,000 & $\begin{array}{l}\mathrm{P}<0,05 \\
\text { (Beda Signifikan) }\end{array}$ \\
\hline $\begin{array}{l}\text { Kapasitas } \\
\text { Vital Paru }\end{array}$ & 2,8278 & 2,9861 & $-0,15833$ & $-6,897$ & 0,000 & $\begin{array}{l}\text { P }<0,05 \\
\text { (Beda Signifikan) }\end{array}$ \\
\hline
\end{tabular}

Hasil analisis sesuai pada tabel di atas menunjukkan bahwa pada kelompok latihan beban terdapat perbedaan antara pretest dengan posttest. Variabel lemak tubuh memiliki nilai $\mathrm{p}=0,000$, dimana $\mathrm{p}<0,05$ berarti ada perbedaan bermakna dan untuk variabel kapasitas vital paru memiliki nilai $\mathrm{p}=0,000$, dimana $\mathrm{p}<0,05$ berarti ada perbedaan bermakna.Berdasarkan analisis tersebut di atas dapat diartikan bahwa latihan beban dapat menurunkan lemak tubuh sebanyak 2,9695 \% dan dapat meningkatkan kemampuan kapasitas vital paru sebesar 0,15833 liter/BTPS.

\section{Hasil Uji beda Variabel Terikat Kelompok Kontrol atau Pembanding}

Hasil analisis perbedaan antara pretest dengan posttets variabel lemak tubuh dan kemampuan kapasitas vital paru pada kelompok kontrol atau pembanding dapat disajikan pada Tabel 3 berikut:

Tabel 3. Hasil Analisis Uji Beda Variabel Terikat Pada Kelompok Kontrol

\begin{tabular}{|c|c|c|c|c|c|c|}
\hline \multirow{2}{*}{ Variabel } & \multicolumn{2}{|l|}{ Mean } & \multirow{2}{*}{$\begin{array}{l}\text { Mean } \\
\text { Delta }\end{array}$} & \multirow{2}{*}{$\mathrm{T}$ test } & \multirow{2}{*}{$\begin{array}{l}\mathrm{P} \\
\text { (Sig.) }\end{array}$} & \multirow{2}{*}{ Ket } \\
\hline & Pre & Post & & & & \\
\hline $\begin{array}{l}\text { Lemak } \\
\text { Tubuh }\end{array}$ & 29,7067 & 30,2231 & $-0,51639$ & $-0,678$ & 0,507 & $\begin{array}{l}\mathrm{P}>0,05 \\
\text { (tidak ada perbedaan yang } \\
\text { signifikan) }\end{array}$ \\
\hline $\begin{array}{l}\text { Kapasitas } \\
\text { Vital Paru }\end{array}$ & 2,7756 & 2,7433 & 0,03222 & 0,588 & 0,564 & $\begin{array}{l}\mathrm{P}>0,05 \\
\text { (tidak ada perbedaan yang } \\
\text { signifikan) }\end{array}$ \\
\hline
\end{tabular}


Hasil analisis sesuai pada tabel di atas menunjukkan bahwa pada kelompok kontrol atau pembanding terdapat perbedaan antara pretest dengan posttest. Variabel lemak tubuh memiliki nilai $\mathrm{p}=0,507$, dimana nilai $\mathrm{p}>0,05$ berarti tidak ada perbedaan bermakna dan untuk variabel kapasitas vital paru memiliki nilai $\mathrm{p}=0,564$ dimana nilai $\mathrm{p}>0,05$ berarti tidak ada perbedaan bermakna. Berdasarkan analisis tersebut di atas dapat diartikan bahwa latihan pada kelompok kontrol tidak dapat menurunkan lemak tubuh tetapi terjadi kenaikan lemak tubuh sebanyak 0,51639\% dan tidak dapat meningkatkan kemampuan kapasitas vital paru. Adapun nilai penurunan kemampuan kapasitas vital paru pada kelompok kontrol ini sebesar 0,03222 liter/BTPS.

\section{Hasil Uji Beda dari Variabel Terikat Antar Kelompok}

Uji beda dari variabel terikat ini bertujuan untuk mengetahui perbedaan pengaruh antar kelompok dari latihan aerobik dan latihan beban terhadap lemak tubuh dan kapasitas vital paru.

\section{Variabel Lemak Tubuh}

Hasil analisis perbedaan pengaruh latihan pada kelompok latihan aerobik, latihan beban dan latihan pada kontrol terhadap lemak tubuh adalah sebagai berikut:

Tabel 4. Hasil Uji Beda Variabel Lemak Tubuh

\begin{tabular}{llll}
\hline Variabel & Nilai F & $\mathrm{P}($ Sig. $)$ & Ket \\
\hline Lemak tubuh & 24,991 & 0,000 & $\begin{array}{l}\mathrm{P}<0,05 \\
\text { Berbeda signifikan }\end{array}$ \\
\hline
\end{tabular}

Berdasarkan analisis yang disajikan pada Tabel 29 tersebut di atas, diperoleh nilai $\mathrm{F}$ hitung $=24,991$ dan nilai taraf signifikan $(\mathrm{p})$ yang diperoleh yaitu 0,000 . Karena nilai $\mathrm{p}=$ $0,000<0,05(\mathrm{p}<0,05)$ maka ada perbedaan yang bermakna pada variabel lemak tubuh antara kelompok perlakuan. Untuk mengetahui kelompok yang berbeda maka dapat dijelaskan pada tabel berikut:

Tabel 5. Hasil Analisis Uji Lanjut dengan LSD

\begin{tabular}{|c|c|c|c|c|c|}
\hline Variabel & $\begin{array}{l}\text { Kelompok } \\
\text { (A) }\end{array}$ & $\begin{array}{l}\text { Kelompok } \\
\text { Perlakuan } \\
\text { (B) }\end{array}$ & $\begin{array}{l}\text { Mean } \\
\text { Difference } \\
(\mathrm{A}-\mathrm{B})\end{array}$ & $\begin{array}{l}\text { P } \\
\text { (Sig.) }\end{array}$ & Keterangan \\
\hline \multirow{6}{*}{$\begin{array}{l}\text { Lemak } \\
\text { Tubuh }\end{array}$} & \multirow[b]{2}{*}{$\begin{array}{l}\text { Latihan } \\
\text { Aerobik }\end{array}$} & Latihan Beban & 1,68617 & 0,028 & Signifikan \\
\hline & & Kontrol & 5,16750 & 0,000 & $\begin{array}{l}\text { Sangat } \\
\text { Signifikan }\end{array}$ \\
\hline & \multirow[b]{2}{*}{$\begin{array}{l}\text { Latihan } \\
\text { Beban }\end{array}$} & Latihan Aerobik & $-1,68167$ & 0,028 & Signifikan \\
\hline & & Kontrol & 3,48583 & 0,000 & $\begin{array}{l}\text { Sangat } \\
\text { Signifikan }\end{array}$ \\
\hline & \multirow{2}{*}{$\begin{array}{l}\text { Kontrol/ } \\
\text { Pembanding }\end{array}$} & Latihan Aerobik & $-5,16750$ & 0,000 & $\begin{array}{l}\text { Sangat } \\
\text { Signifikan }\end{array}$ \\
\hline & & Latihan Beban & $-3,48583$ & 0,000 & $\begin{array}{l}\text { Sangat } \\
\text { Signifikan }\end{array}$ \\
\hline
\end{tabular}

Berdasarkan data nilai pada penyajian tabel di atas dapat dijelaskan bahwa:

a. Perbedaan Mean Difference lemak tubuh kelompok latihan aerobik dengan kelompok latihan beban yaitu sebesar $1,68167 \%$, dimana $\mathrm{p}=0,028$ dan $\mathrm{p}<0,05$. Hal tersebut dapat diartikan bahwa ada perbedaan yang signifikan diantara kedua kelompok latihan. Latihan aerobik dapat menurunkan lemak tubuh lebih banyak dari pada latihan beban.

b. Perbedaan Mean Difference lemak tubuh kelompok latihan aerobik dengan kelompok kontrol yaitu sebesar $5,16750 \%$, dimana $\mathrm{p}=0,000$ dan $\mathrm{p}<0,05$. Hal tersebut dapat 
diartikan bahwa ada perbedaan yang signifikan diantara kedua kelompok latihan. Latihan aerobik lebih banyak menurunkan lemak dibanding dengan latihan yang dilakukan kelompok kontrol atau pembanding.

c. Perbedaan Mean Difference lemak tubuh kelompok latihan beban dengan kelompok kontrol yaitu sebesar 3,48583 \%, dimana $\mathrm{p}=0,000$ dan $\mathrm{p}<0,05$. Hal tersebut dapat diartikan bahwa ada perbedaan yang signifikan diantara kedua kelompok latihan. Latihan beban lebih banyak menurunkan lemak tubuh dibanding latihan yang dilakukan kelompok kontrol atau pembanding.

\section{Variabel Kapasitas Vital Paru}

Hasil analisis perbedaan pengaruh latihan pada kelompok latihan aerobik, latihan beban dan latihan pada kontrol terhadap kapasitas vital paru adalah sebagai berikut:

Tabel 6. Hasil Uji Beda Variabel Kapasitas Vital Paru

\begin{tabular}{llll}
\hline Variabel & Nilai F & $\mathrm{P}$ (Sig.) & Ket \\
\hline Kapasitas Vital Paru & 11,184 & 0,000 & $\begin{array}{l}\mathrm{P}<0,05 \\
\text { Signifikan }\end{array}$ \\
\hline
\end{tabular}

Berdasarkan analisis yang disajikan pada Tabel 31 tersebut di atas, diperoleh nilai $\mathrm{F}$ hitung $=11,184$ dan nilai taraf signifikan $(\mathrm{p})$ yang diperoleh yaitu 0,000 . Karena nilai $\mathrm{p}=$ $0,000<0,05(\mathrm{p}<0,05)$ maka ada perbedaan yang bermakna pada variabel kapasitas vital paru antara kelompok perlakuan. Untuk mengetahui kelompok yang berbeda maka dapat dijelaskan pada tabel berikut ini:

Tabel 7. Hasil Analisis Uji Lanjut dengan LSD

\begin{tabular}{llllll}
\hline \multirow{2}{*}{ Variabel } & $\begin{array}{l}\text { Kelompok } \\
(\mathrm{A})\end{array}$ & $\begin{array}{l}\text { Kelompok } \\
\text { Perlakuan } \\
(\mathrm{B})\end{array}$ & $\begin{array}{l}\text { Mean } \\
\text { Difference } \\
(\mathrm{A}-\mathrm{B})\end{array}$ & $\begin{array}{l}\mathrm{P} \\
(\text { Sig. })\end{array}$ & Keterangan \\
\hline \multirow{4}{*}{$\begin{array}{l}\text { Kapasitas } \\
\text { Vital Paru }\end{array}$} & $\begin{array}{l}\text { Latihan } \\
\text { Aerobik }\end{array}$ & Latihan Beban & 0,05833 & 0,294 & Tidak Signifikan \\
\cline { 2 - 6 } & Latihan & Kontrol & 0,24889 & 0,000 & Signifikan \\
\cline { 2 - 6 } & Beban & Kontrol & 0,05833 & 0,294 & Tidak Signifikan \\
\cline { 2 - 6 } & Kontrol/ & Latihan Aerobik & $-0,24889$ & 0,001 & Signifikan \\
\cline { 3 - 6 } & Pembanding & Latihan Beban & $-0,19056$ & 0,000 & Signifikan \\
\hline
\end{tabular}

Berdasarkan data nilai pada penyajian tabel di atas dapat dijelaskan bahwa:

a. Perbedaan Mean Difference kapasitas vital paru pada kelompok latihan aerobik dengan kelompok latihan beban yaitu sebesar 0,05833 liter/BTPS dimana $\mathrm{p}=0,294$ dan $\mathrm{p}>0,05$. Hal tersebut dapat diartikan bahwa tidak ada perbedaan yang signifikan diantara kedua kelompok latihan. Latihan aerobik dan latihan beban sama-sama meningkatkan kemampuan kapasitas vital paru.

b. Perbedaan Mean Difference kapasitas vital paru pada kelompok latihan aerobik dengan kelompok kontrol yaitu sebesar 0,24889 liter/BTPS, dimana $\mathrm{p}=0,000$ dan $\mathrm{p}<0,05$. Hal tersebut dapat diartikan bahwa ada perbedaan yang signifikan diantara kedua kelompok latihan. Latihan aerobik dapat meningkatkan kemampuan kapasitas vital paru lebih banyak dari pada kelompok latihan kontrol atau pembanding.

c. Perbedaan Mean Difference kapasitas vital paru kelompok latihan beban dengan kelompok kontrol yaitu sebesar 0,19056 liter/BTPS, dimana $p=0,001$ dan $p<0,05$. Hal tersebut dapat diartikan bahwa ada perbedaan yang signifikan diantara kedua kelompok latihan. Kelompok latihan beban lebih banyak meningkatkan kemampuan kapasitas vital paru dibandingkan latihan pada kelompok kontrol atau pembanding. 


\section{PEMBAHASAN}

Pada bagian pembahasan ini akan dibahas hasil penelitian sesuai dengan data-data yang ada. Adapun variabel bebas atau perlakuan pada penelitian ini yaitu latihan aerobik dan latihan beban, sedangkan variabel terikat terdiri atas lemak tubuh dan kapasitas vital paru.

\section{Pengaruh Latihan Aerobik terhadap Lemak Tubuh dan Kapasitas Vital Paru}

Hasil analisis data penelitian menunjukkan bahwa pada kelompok latihan aerobik terjadi perbedaan hasil antara data pretest dengan data posttest variabel lemak tubuh yaitu nilai pretest sebesar 30,5728 dan data posttest sebesar 25,9217 , mean delta variabel lemak ini adalah sebesar 4,65111. Latihan aerobik juga menghasilkan nilai perbedaan yang signifikan yaitu nilai $\mathrm{p}=0,000$ dan $\mathrm{p}<0,05$. Data tersebut menggambarkan bahwa latihan aerobik dapat menurunkan lemak tubuh sebanyak 4,65111\%. Nilai tersebut merupakan hasil selisih antara nilai posttest dikurangi nilai pretest, sehingga terjadi perbedaan yang signifikan diantara kedua data tersebut.

Data perbedaan hasil lemak tubuh antara pretest dan postest pada kelompok latihan aerobik dapat dilihat pada gambar 1 di bawah ini:

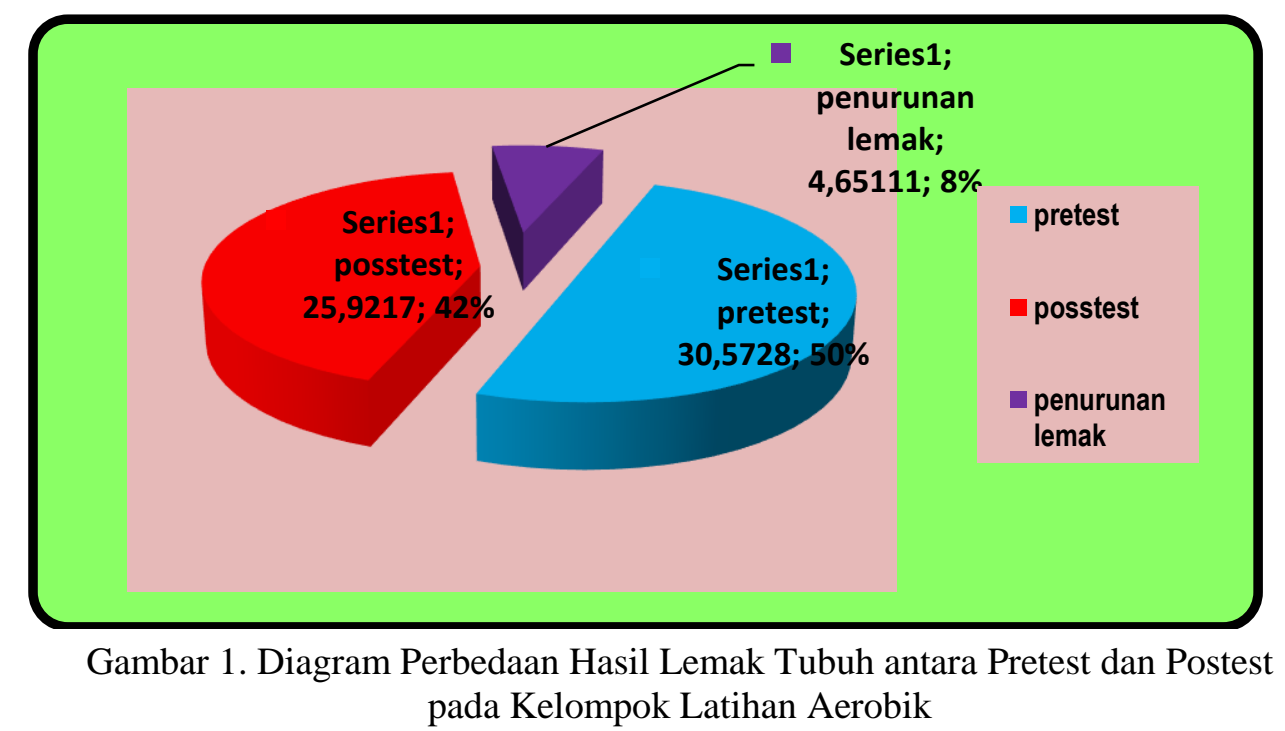

Hasil tersebut dapat dijelaskan bahwa dengan melakukan latihan aerobik dengan intensitas latihan sebesar $65 \%$ sampai dengan $85 \%$ dari detak jantung maksimum dan dilakukan selama 30 menit, maka akan membantu proses pembakaran lemak di dalam tubuh. Hal ini dapat dibuktikan bahwa dengan melakukan latihan aerobik maka akan terjadi peningkatan kapasitas oksidasi lemak di dalam sel otot yang disebabkan oleh meningkatnya penyimpanan trigliserida di dalam intramuskular, yang disimpan dalam bentuk lemak, meningkatnya pengeluaran asam lemak bebas dari jaringan lemak, sehingga tersedianya lemak sebagai bahan bakar menjadi meningkat, dan meningkatnya kegiatan enzim di dalam tubuh manusia yang terlibat didalam aktivitas transport maupun pada proses pemecahan asam lemak (Junusul, 1989). Selain itu menurut Lynne Brick (2001) bahwa dengan melakukan latihan aerobik yang dilakukan dengan intensitas rendah sampai intensitas sedang selama 30 menit akan membakar kira-kira 250 kalori, dan apabila dilakukan pada intesitas rendah sampai intensitas sedang selama 20 menit atau lebih, maka akan membakar lemak di dalam tubuh.

Sadoso (1996) menyatakan bahwa latihan aerobik dapat menaikkan kecepatan metabolisme (kecepatan membakar kalori) sebanyak 25\% selama 15 jam setelah melakukan latihan, dan sebanyak 10\% selama 48 jam setelah berolahraga. Selain itu dianjurkan untuk 
penurunan berat badan yang aman dan efektif yaitu dengan latihan olahraga secara aerobik karena dengan olahraga ini, lemak yang hilang akan lebih banyak sedangkan jaringan otot tidak ikut terkikis (Sadoso, 1996: 93).

Selain itu pada saat melakukan latihan, lemak dipecah menjadi asam lemak dan gliserol. Asam lemak bebas diangkut ke jaringan otot dan dipergunakan sebagai energi. Namun pembentukan energi dari asam lemak membutuhkan oksigen lebih banyak dibanding karbohidrat. Lemak hanya dapat menghasilkan energi bila oksigen tersedia atau cukup. Jadi lemak dapat menghasilkan energi hanya pada olahraga yang bersifat aerobik. Jadi dapat disimpulkan sesuai analisis data penelitian bahwa dengan melakukan latihan aerobik dengan intensitas $65 \%$ - 85\% dari detak jantung maksimal, dilakukan selama 30 menit setiap latihan, frekuensi 3 kali per minggu dan dilakukan selama 24 kali pertemuan (8 minggu), terjadi penurunan lemak tubuh sebesar $4,65111 \%$.

Latihan aerobik dapat meningkatkan kapasitas vital paru, karena pada saat latihan, sistem respirasi sangat diperlukan untuk membantu proses penggunaan energi yaitu dari penggunaan oksigen. Proses latihan ini akan mengakibatkan perubahan pada sistem paru, dimana paru-paru akan bekerja lebih keras untuk menggunakan oksigen yang berasal dari lingkungan sekitar. Selain itu, disaat olahraga paru-paru akan bekerja menyediakan sumber oksigen untuk darah dan darah membuang karbondioksida (CO2) yang diambil atau berasal dari sel-sel yang aktif bekerja. Selama melakukan latihan aerobik, jumlah udara yang dikeluarkan paru-paru dapat naik sampai 100 liter bagi orang biasa dan bagi atlet yang benar-benar terlatih dapat mencapai 200 liter per menit, sedangkan frekuensi pernapasan normalnya adalah 10-15 kali per menit pada waktu kerja maksimal (Sadoso, 1990: 82).

Dari pernyataan diatas dapat dijadikan suatu dasar bahwa dengan melakukan latihan aerobik secara teratur maka dapat meningkatkan fungsi kerja paru dimana kapasitas vital paru menjadi meningkat. Ini dapat dilihat dari hasil pretest sebesar 2,8056 liter/BTPS dan posttest sebesar 3,0222 liter/BTPS. Sesuai dengan analisis data penelitian bahwa hasil peningkatan kapasitas vital paru melalui latihan aerobik yaitu sebesar 0,21667 liter/BTPS.

Data perbedaan hasil kapasitas vital paru antara pretest dan postest pada kelompok latihan aerobik dapat dilihat pada gambar 2 di bawah ini:

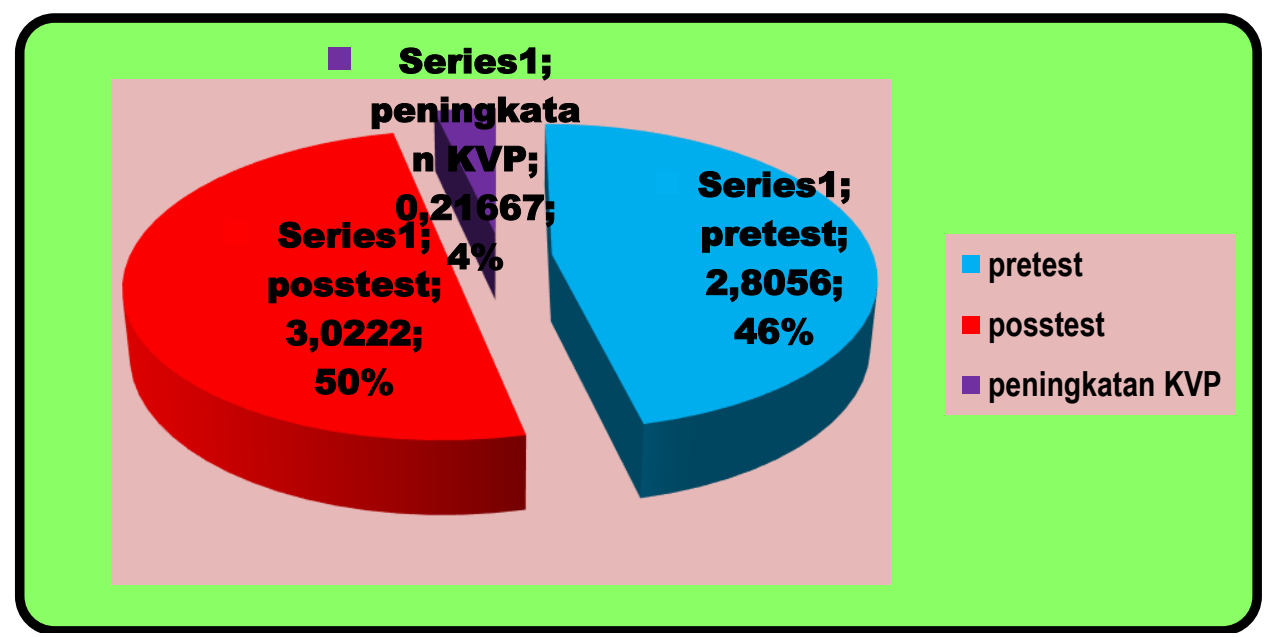

Gambar 2. Diagram Perbedaan Hasil Kapasitas Vital Paru antara Pretest dan Posttest pada Kelompok Latihan Aerobik

\section{Pengaruh Latihan Beban terhadap Lemak Tubuh dan Kapasitas Vital Paru}

Hasil analisis data penelitian menunjukkan bahwa pada kelompok latihan beban terjadi perbedaan hasil antara data pretest dengan data posttest variabel lemak tubuh yaitu nilai pretest sebesar 28,5267 dan data posttest sebesar 25,5572, mean delta variabel lemak ini adalah sebesar 2,96944. Latihan aerobik juga menghasilkan nilai perbedaan yang 
signifikan yaitu nilai $\mathrm{p}=0,000$ dan $\mathrm{p}<0,05$. Data tersebut menggambarkan bahwa latihan beban dapat menurunkan lemak tubuh sebanyak 2,96944\%. Nilai tersebut merupakan hasil selisih antara nilai posttest dikurangi nilai pretest, sehingga terjadi perbedaan yang signifikan diantara kedua data tersebut.

Data perbedaan hasil lemak tubuh antara pretest dan postest pada kelompok latihan beban dapat dilihat pada gambar 3 di bawah ini:

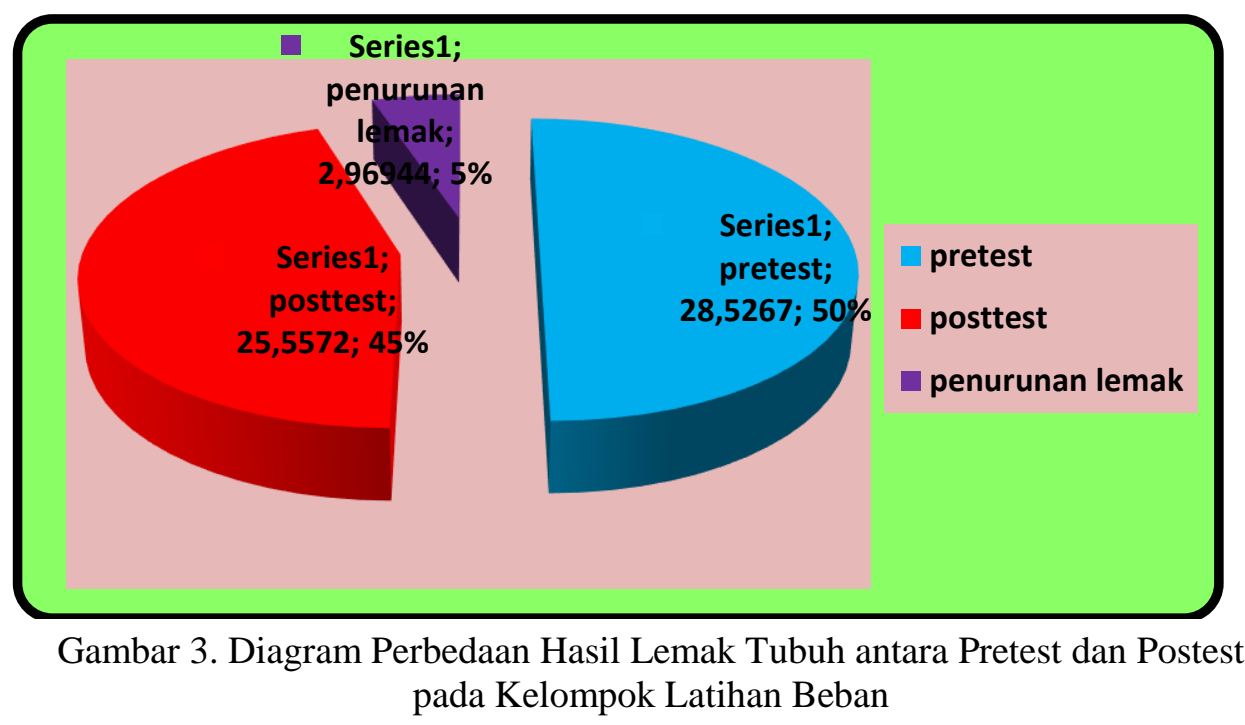

Hasil tersebut dapat dijelaskan bahwa dengan melakukan latihan beban dengan intensitas latihan sebesar 60\% sampai dengan 70\% dari kemampuan maksimum, frekuensi 3 kali perminggu, repetisi 15 ulangan, dengan 10 alat atau pos stasiun dilakukan selama 44 menit, maka akan membantu proses pembakaran lemak di dalam tubuh. Sesuai dengan penelitian Djoko (2009) latihan beban dengan cara sirkuit intensitas rendah (intensitas 60\%70\%) dapat memperbaiki profil lemak (mengurangi lemak subkutan) sebanyak 6,53333\%. Hal tersebut dikarenakan gerakan latihan beban tersebut dilakukan dengan ritme cepat sehingga mampu meningkatkan detak jantung mencapai intensitas aerobik, dan intensitas aerobik itulah yang dapat memacu lipolisis yakni pemecahan trigliserida menjadi asam lemak dan gliserol sehingga akan meningkatkan pembakaran lemak. Senada dengan (Lestari \& Nasrulloh, 2019) dalam artikelnya menyebutkan bahwa: (1) Ada pengaruh yang signifikan body weight training menggunakan resistance band terhadap penueunan berat badan dan persentase lemak dengan nilai signifikasi $(\mathrm{p}<0,05)$, (2) Ada pengaruh body weight training tanpa resistance band terhadap penurunan berat badan persentase lemak dengan nilai signifikasi $(\mathrm{p}<0,05)$. (3) Dapat dibuktikan juga bahwa latihan beban body weight training menggunkan resistance band lebih efektif dari pada tanpa resistance band terhadap penurunan berat badan dan persentase lemak. Sesuai dengan hasil penelitian diatas maka dapat dijadikan acuan bahwa latihan beban dapat menurunkan lemak tubuh. Analisis data penelitian ini bahwa dengan melakukan latihan beban sesuai takaran diatas dapat menurunkan lemak tubuh sebanyak 2,96944\%. Metode circuit weight training lebih efektif dari pada metode super set untuk menurunkan berat badan dan prosentase lemak. Hal ini dibuktikan dengan nilai prosentase pada penurunan berat badan antara metode circuit weight training dengan metode super set sebesar 4,6\% yang lebih besar dari 2,6\% dan nilai prosentase penurunan prosentase lemak antara metode circuit weight training dengan metode super set sebesar 19,2 \% yang lebih besar dari 10,5 \% (Purwanto \& Nasrulloh, 2019).

Selain itu, latihan beban juga dapat meningkatkan kapasitas vital paru. Hal tersebut dikarenakan karena dalam melakukan latihan beban sistem respirasi atau pernafasan juga 
sangat berperan. Apabila respirasi atau pernafasan saat melakukan latihan beban diabaikan maka akan berakibat vital bagi tubuh manusia, karena saat kontraksi dan nafas ditahan maka akan menghambat aliran darah ke otak dan otak tidak mampu beraktivitas tanpa adanya oksigen. Hal tersebut menyebabkan orang akan merasa pusing atau sampai tidak sadarkan diri (Thomas. R, 1996). Adapun sistem pernafasan yang benar pada saat latihan beban yaitu mengeluarkan nafas saat melakukan konstraksi/mengangkat beban dan menarik nafas pada saat mengendorkan otot (relaksasi). Secara tidak langsung, menurut pernyataan diatas bahwa dalam melakukan latihan beban maka sistem respirasi memiliki peran penting. Sistem ini lah yang mengakibatkan kerja paru lebih optimal dalam menghasilkan oksigen sebanyak-banyaknya. Jika sering dilatih dan dilaksanakan dengan baik, maka akan terjadi perkembangan pada fungsi paru sehingga akan mengakibatkan meningkatnya kapasitas vital paru.

Data analisis penelitian ini, menunjukkan bahwa terdapat perbedaan rerata antara pretest dan posttest nilai kemampuan kapasitas vitas paru pada kelompok latihan beban. Adapun nilai pretest sebesar 2,8278 liter/BTPS dan posttest sebesar 2,9861liter/BTPS. Besarnya selisih antara kedua nilai tersebut yaitu sebesar 0,15833. Nilai ini merupakan nilai peningkatan kapasitas vital paru pada kelompok latihan beban. Data perbedaan hasil kapasitas vital paru antara pretest dan postest pada kelompok latihan beban dapat dilihat pada gambar 4 di bawah ini:

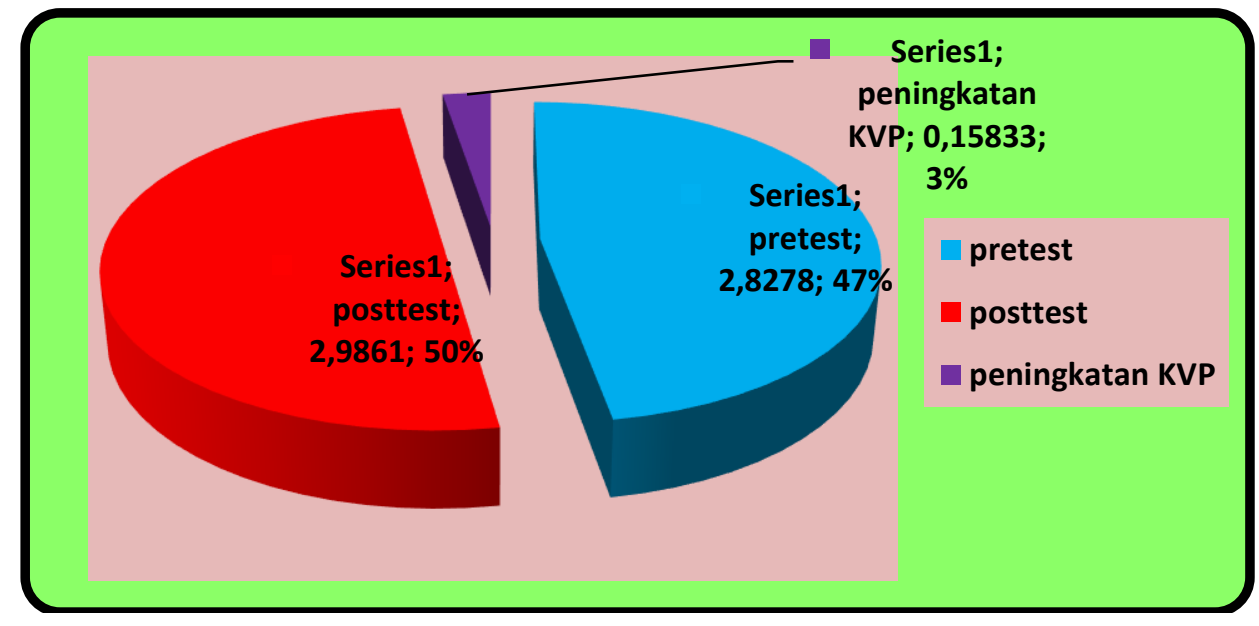

Gambar 4. Diagram Perbedaan Hasil Kapasitas Vital Paru antara Pretest dan Posttest pada Kelompok Latihan Beban

\section{Perbedaaan Pengaruh Antara Kelompok Latihan Aerobik, Latihan Beban dan Kelompok Latihan Kontrol atau Pembanding terhadap Lemak Tubuh}

Berdasarkan analisis data penelitian, perbedaan pengaruh antara kelompok latihan aerobik, latihan beban dan latihan kontrol terhadap lemak tubuh diperoleh nilai $\mathrm{F}$ hitung = 24,991 dan nilai taraf signifikan (p) yang diperoleh yaitu 0,000 . Karena nilai $p=0,000<$ $0,05(\mathrm{p}<0,05)$ maka ada perbedaan yang bermakna pada variabel lemak tubuh antara kelompok perlakuan, dimana setiap kelompok memiliki perbedaan yang signifikan. Perbedaan rerata lemak tubuh antara kelompok latihan aerobik dengan kelompok latihan beban yaitu sebesar $1,68167 \%$, dimana $\mathrm{p}=0,028$ dan $\mathrm{p}<0,05$. Hal tersebut dapat diartikan bahwa ada perbedaan yang signifikan diantara kedua kelompok latihan. Latihan aerobik dapat menurunkan lemak tubuh lebih sebanyak 1,68167 \% dari pada latihan beban.

Perbedaan rerata lemak tubuh kelompok latihan aerobik dengan kelompok kontrol yaitu sebesar 5,16750 \%, dimana $\mathrm{p}=0,000$ dan $\mathrm{p}<0,05$. Hal tersebut dapat diartikan bahwa ada perbedaan yang signifikan diantara kedua kelompok latihan. Kelompok latihan aerobik 
terjadi penurunan lemak tubuh lebih sebanyak 5,16750 \% dari pada kelompok latihan kontrol atau pembanding. Jadi latihan aerobik lebih banyak menurunkan lemak dibanding dengan latihan yang dilakukan kelompok kontrol atau pembanding. Perbedaan rerata lemak tubuh kelompok latihan beban dengan kelompok kontrol yaitu sebesar 3,48583\%, dimana $\mathrm{p}=0,000$ dan $\mathrm{p}<0,05$. Hal tersebut dapat diartikan bahwa ada perbedaan yang signifikan diantara kedua kelompok latihan. Kelompok latihan beban terjadi penurunan lemak tubuh lebih sebanyak 3,48583\% dari pada kelompok latihan kontrol atau pembanding. Jadi latihan beban lebih banyak menurunkan lemak tubuh dibanding latihan yang dilakukan kelompok kontrol atau pembanding. Dari penjelasan di atas dapat disimpulkan bahwa latihan aerobik lebih banyak menurunkan lemak tubuh dibanding latihan beban maupun latihan yang dilakukan kelompok kontrol atau pembanding.

Hasil tersebut dapat dijelaskan bahwa latihan aerobik dengan intensitas latihan sebesar $65 \%$ sampai dengan $85 \%$ dari detak jantung maksimum dan dilakukan selama 30 menit, akan membantu proses pembakaran lemak di dalam tubuh. Hal ini dapat dibuktikan bahwa dengan melakukan latihan aerobik maka akan terjadi peningkatan kapasitas oksidasi lemak di dalam sel otot yang disebabkan oleh meningkatnya penyimpanan trigliserida di dalam intramuskular, yang disimpan dalam bentuk lemak, meningkatnya pengeluaran asam lemak bebas dari jaringan lemak, sehingga tersedianya lemak sebagai bahan bakar menjadi meningkat, dan meningkatnya kegiatan enzim di dalam tubuh manusia yang terlibat didalam aktivitas transport maupun pada proses pemecahan asam lemak (Junusul, 1989: 210). Selain itu aktivitas latihan aerobik sangatlah komplek karena gerakan yang dilakukan melibatkan seluruh anggota tubuh sehingga akan menimbulkan kenaikan pada detak jantung yang memacu tercapainya intensitas latihan untuk pembakaran lemak. Peningkatan yang signifikan pada kelompok latihan aerobik ini juga dikarenakan adanya takaran dan dosis latihan yang tepat dan sesuai dengan sampel kelompok aerobik sehingga latihan pun dapat terlaksana dengan sungguh-sungguh.

Adapun perbandingan atau perbedaan penurunan persentase lemak tubuh dapat disajikan melalui histogram dibawah ini:

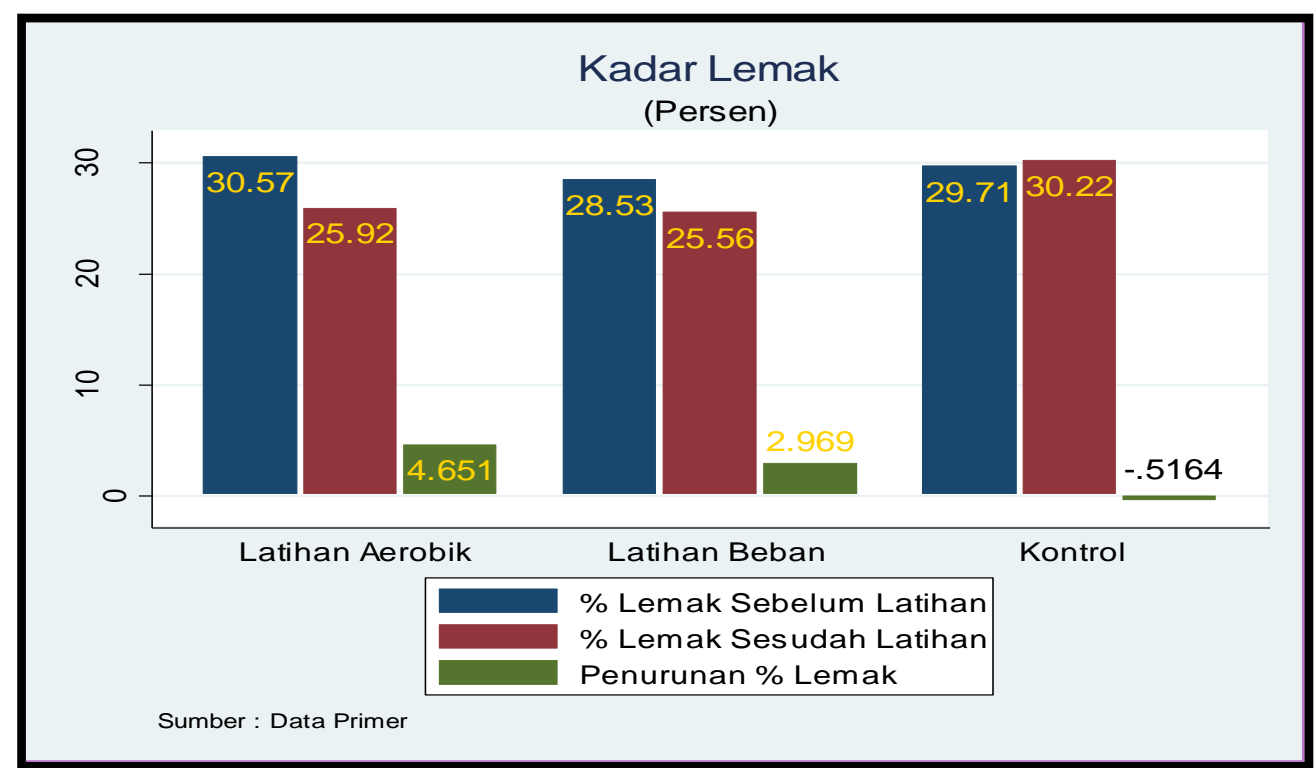

Gambar 5. Histogram Data Persentase Lemak Tubuh Pada Masing-Masing Kelompok 


\section{Perbedaaan Pengaruh Antara Kelompok Latihan Aerobik, Latihan Beban dan Kelompok Latihan Kontrol atau Pembanding terhadap Kapasitas Vital Paru}

Berdasarkan analisis data penelitian, perbedaan pengaruh antara kelompok latihan aerobik, latihan beban dan latihan kontrol terhadap kapasitas vital paru diperoleh nilai $\mathrm{F}$ hitung 11,184 dan nilai taraf signifikan (p) yang diperoleh yaitu 0,000 . Karena nilai $\mathrm{p}=$ $0,000<0,05(\mathrm{p}<0,05)$ maka ada perbedaan yang bermakna pada variabel kapasitas vital paru antara kelompok perlakuan. Perbedaan rerata kapasitas vital paru pada kelompok latihan aerobik dengan kelompok latihan beban yaitu sebesar 0,05833 liter/BTPS dimana $\mathrm{p}=0,294$ dan $\mathrm{p}>0,05$. Hal tersebut dapat diartikan bahwa tidak ada perbedaan yang signifikan diantara kedua kelompok latihan. Latihan aerobik dan latihan beban sama-sama meningkatkan kemampuan kapasitas vital paru.

Perbedaan rerata kapasitas vital paru pada kelompok latihan aerobik dengan kelompok kontrol yaitu sebesar 0,24889 liter/BTPS, dimana $\mathrm{p}=0,000$ dan $\mathrm{p}<0,05$. Hal tersebut dapat diartikan bahwa ada perbedaan yang signifikan diantara kedua kelompok latihan. Latihan aerobik dapat meningkatkan kemampuan kapasitas vital paru lebih banyak dari pada kelompok latihan kontrol atau pembanding. Adapun besarnya peningkatan kapasitas vital paru tersebut sebesar 0,24889 liter/BTPS. Perbedaan rerata kapasitas vital paru kelompok latihan beban dengan kelompok kontrol yaitu sebesar 0,19056 liter/BTPS, dimana $\mathrm{p}=0,001$ dan $\mathrm{p}<0,05$. Hal tersebut dapat diartikan bahwa ada perbedaan yang signifikan diantara kedua kelompok latihan. Kelompok latihan beban lebih banyak meningkatkan kemampuan kapasitas vital paru dibandingkan latihan pada kelompok kontrol atau pembanding. Adapun besarnya peningkatan kapasitas vital paru pada latihan beban yaitu sebesar 0,19056 liter/BTPS. Dari penjelasan di atas dapat disimpulkan bahwa latihan aerobik lebih banyak meningkatkan kemampuan kapasitas vital paru dibanding latihan beban maupun latihan yang dilakukan kelompok kontrol atau pembanding.

Hasil tersebut dapat dijelaskan bahwa latihan aerobik dengan intensitas latihan sebesar $65 \%$ sampai dengan $85 \%$ dari detak jantung maksimum dan dilakukan selama 30 menit ini dapat memacu terjadinya perubahan pada sistem kardiorespirasi dan secara tidak langsung akan berpengaruh pada sistem transport oksigen. Senada dengan hasil penelitiannya Nasrulloh (2014) bahwa ada pengaruh yang signifikan antara physical fitness programme terhadap maximum oxygen uptake (kesehatan paru). Sistem transport oksigen juga melibatkan sistem sirkulatori, respiratori, dan jaringan. Komponen tersebut bekerja bersama-sama untuk melepaskan/ menyampaikan oksigen ke otot dan seluruh organ lain yang beraktivitas, dengan demikian perubahan pada sistem respirasi ini dapat meningkatkan perubahan pada kerja paru sehingga kapasitas vital paru pun meningkat. Menurut Djoko (2004) latihan untuk meningkatkan daya tahan aerobik yaitu pada intensitas $75 \%$ - 85\% dari detak jantung maksimal, waktu atau durasi yang dilakukan selama 20 - 60 menit setiap latihan. Jadi untuk intensitas latihan yang telah dilaksanakan pada penelitian ini sesuai dengan intensitas latihan aerobik dan sampel dapat melaksanakan dengan baik sehingga disaat latihan berlangsung, intensitas yang harus dicapai dapat terlaksana.

Lain halnya dengan kelompok latihan beban atau latihan pada kelompok kontrol. Kelompok latihan beban dapat menaikkan kapasitas paru tetapi tidak sebanyak latihan aerobik dikarenakan saat melakukan latihan, sampel kurang sungguh-sungguh dalam melaksanakannya. Selain itu pada proses perpindahan alat dari satu alat ke alat yang lain, terjadi istirahat yang terlalu lama karena antri menunggu alat. Hal tersebut mengakibatkan intensitas latihan tidak tercapai dan sistem kardiorespirasi tidak maksimal. Begitupun pada kelompok latihan kontrol, kelompok ini tidak diberikan perlakuan yang khusus, sehingga saat latihan kelompok tersebut hanya latihan sesuai keinginannya. Oleh sebab itu pada penelitian ini kelompok latihan kontrol tidak dapat meningkatkan kapasitas vital paru. 
Adapun perbandingan atau perbedaan peningkatan kemampuan kapasitas vital paru dapat disajikan melalui histogram dibawah ini:

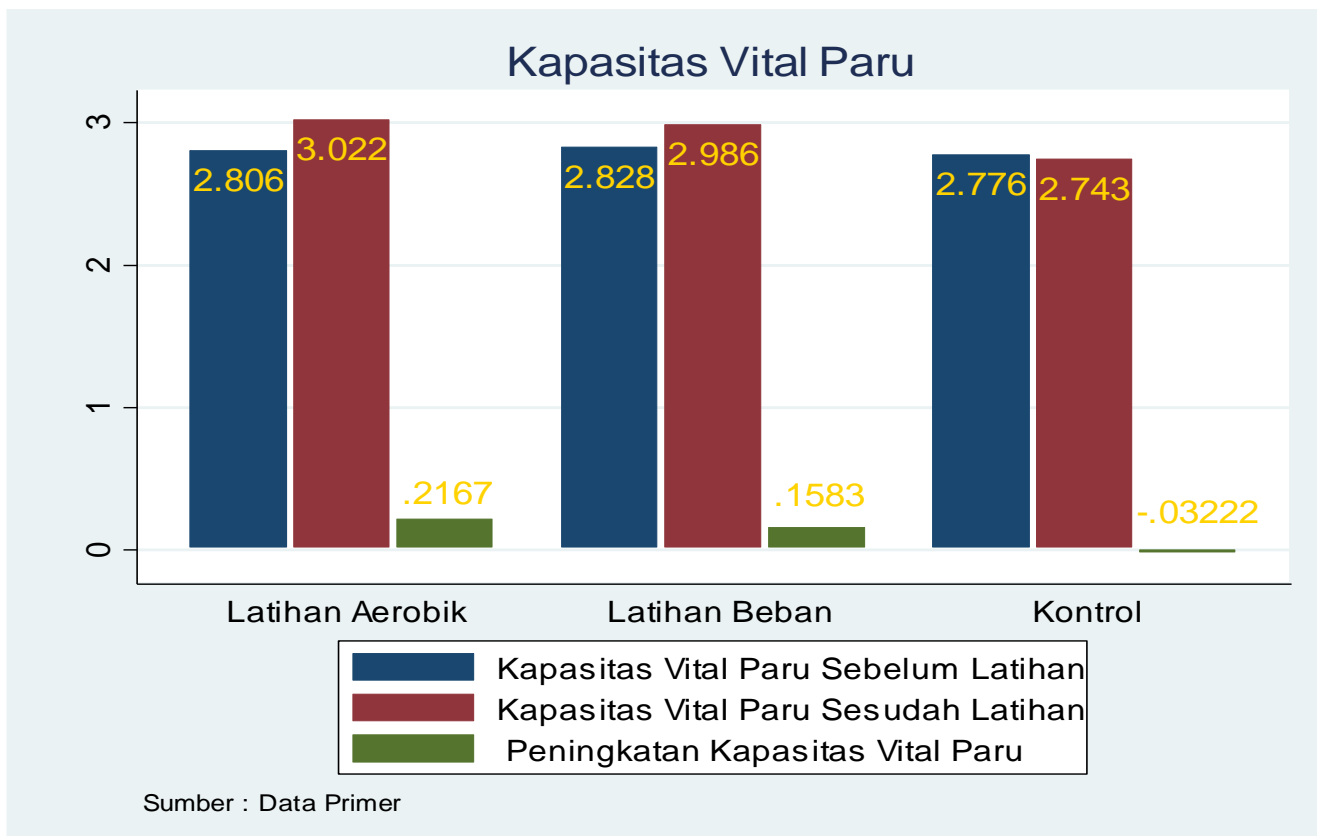

Gambar 6. Histogram Data Kemampuan Kapasitas Vital Paru Pada Masing-Masing Kelompok

\section{SIMPULAN}

Berdasarkan hasil penelitian tentang pengaruh latihan aerobik dan latihan beban terhadap lemak tubuh dan kapasitas vital paru, maka dapat ditarik kesimpulan sebagai berikut: 1) Latihan aerobik dapat menurunkan lemak tubuh sebesar 4,651\% dan meningkatkan kapasitas vital paru pada member di Fitness Center sebesar 0,2167 liter/BTPS; 2) Latihan beban dapat menurunkan lemak tubuh sebesar 2,969 \%; 3) Latihan beban dapat meningkatkan kapasitas vital paru sebesar 0,1583 liter/BTPS; 4) Latihan aerobik dapat menurunkan lemak tubuh lebih tinggi dibanding latihan beban di Fitness Center, yaitu sebesar 1,68617\%.

Latihan aerobik dapat meningkatkan kemampuan kapasitas vital paru lebih tinggi dibanding latihan beban di Fitness Center, yaitu sebesar 0,05833 liter/BTPS.

\section{DAFTAR PUSTAKA}

Baechle, T. R. and Earle, R. W. (2014). Weight Training Steps to Success. United States: Human Kinetics.

Baechle, T. R. and Earle, R. W. (2012). Fitness Weight Training. United States: Human Kinetics.

Baechle, T.R and Roger, W.E. (1996). Fitness Weight Training. Alih Bahasa Bugar dengan Latihan Beban oleh: Razi Siregar, Jakarta: PT. Raja Grafindo Persada

Brick, Lyne. (2002). Fitness Aerobic. (Alih bahasa: Anna Agustina), Jakarta: PT. Raja Grafindo Persada

Djoko Pekik Irianto. (2004). Pedoman praktis berolahraga. Yogyakarta: Andi Offset. 
Djoko Pekik Irianto. (2007). Panduan Gizi Lengkap (Keluarga dan Olahraga). Yogyakarta: Andi Offset.

Djoko Pekik Irianto. (2009). Peranan jogging dan circuit weight training pada profil lemak tubuh dan kebugaran aerobik penyandang overweight. Disertasi, Universitas Negeri Surabaya. Surabaya.

Guyton, A. C. (1997). Buku ajar fisiologi kedokteran. (Alih bahasa Irawati, S.). Jakarta: EGC Penerbit Buku Kedokteran.

Junusul Hairy. (1989). Fisiologi olahraga. Jakarta: Departemen Pendidikan dan Kebudayaan.

Lestari, A., \& Nasrulloh, A. (2019). Efektivitas Latihan Body Weight Training dengan dan Tanpa Menggunakan Resistance Band terhadap Penurunan Berat Badan dan Persentase Lemak. MEDIKORA. https://doi.org/10.21831/medikora.v17i2.29180

Moh. Nazir. (2003). Metode Penelitian. Jakarta: Ghalia Indonesia.

Nasrulloh, A., (2014). Program Physical Fitness Dalam Meningkatkan Kesehatan Paru (VO2 Max). Jurnal KEMAS. https://doi.org/10.15294/kemas.v10i1.3063

Nasrulloh, A., Prasetyo, Y., \& Apriyanto, K. D. (2018). Dasar-Dasar Latihan Beban. Yogyakarta: UNY Press.

Purwanto, P., \& Nasrulloh, A. (2019). Efektivitas Latihan Beban dengan Metode Circuit Weight Training dengan Super Set terhadap Penurunan Berat Badan dan Prosentase Lemak. MEDIKORA. https://doi.org/10.21831/medikora.v16i1.23484

Sadoso Sumosardjuno. (1990). Pengetahuan praktis kesehatan dalam olahraga 2. Jakarta: PT Gramedia Pustaka Utama.

Sadoso Sumosardjuno. (1996). Pengetahuan praktis kesehatan dalam olahraga. Jakarta: PT Gramedia Pustaka Utama.

Sonny Elwin W. (2005). Profil kapasitas vital paru dan VO2 max pada siswa eks pemakai narkoba panti pamardi putra mandiri Semarang tahun 2004-2005. Skripsi, Diterbitkan, Universitas Negeri Semarang: Semarang.

Sugiarto dan Nanang Indarti. (2007). Korelasi antara VO2 max dan vital capacity dengan ketahanan menyelam pada mahasiswa IKORA angkatan 2006. Proceeding Seminar Nasional PORPERTI. Yogyakarta: Kemahasiswaan UNY Desember 2007.

Werner W. K. H. and Sharon A. H. (2011). Lifetime Physical Fitness and Wellness. Wadsworth: United State of America. 